\title{
To Shed Our Blood for Our Beloved Territory: The Iowa-Missouri Borderland
}

\author{
DEREK R. EVERETT
}

IN THE EARLY NINETEENTH CENTURY Iowa and Missouri engaged in a "border war" with potentially dangerous consequences. For several decades in the early 1800s, the divide between the two trans-Mississippi states evolved through a process of legal wrangling, political posturing, and even the threat of violence. One Iowan remembered a willingness "to shed our blood for our beloved Territory," a sentiment shared by those south of the line. ${ }^{1}$

The feud between Iowa and Missouri has attracted the attention of several scholars over the years. ${ }^{2}$ More often than not seen as little more than an amusing anecdote, in reality the struggle over the Iowa-Missouri line represented something far more important. This internal division in the American West illustrated the value states placed on their boundaries, and the determination

1. J. M. D. Burrows, "Rumors of War," Palimpsest 24 (1943), 72. Burrows served in the Iowa territorial militia during the 1839 "war" with Missouri, and the Palimpsest article reprinted his memoir of the event.

2. Perhaps the most notable earlier work is Caroll J. Kraus, "A Study in Border Controversy: The Iowa-Missouri Boundary Dispute," Annals of Iowa 40 (1969), 81-107. For other sources on the controversy, see Charles Negus, "The Southern Boundary of Iowa," Annals of Iowa, 1st ser., 4 (1866), 743-53, 786-93; Ben Hur Wilson, "The Southern Boundary," Palimpsest 20 (1938) 413-24; Craig Hill, "The Honey War," Pioneer America 14 (July 1982), 81-88; and John Ira Barrett, "The Legal Aspects of the Iowa-Missouri Boundary Dispute, 1839-1851" (M.A. thesis, Drake University, 1959).

THE ANNALS OF IOWA 67 (Fall 2008). (C) The State Historical Society of Iowa, 2008. 
of people living within them to protect both the property they defined and the identity they provided. This article extends earlier interpretations beyond a focus on the "Honey War" of late 1839 to illustrate the succession of events that led up to that conflict, its connection to broader movements in regional and national history, and the legal and social consequences of the controversy.

One of the most hotly contested border regions in American history, the land later split into Iowa and Missouri came to the United States with the Louisiana Purchase in 1803. Many years passed before a serious dispute developed in the region. The line separating these two political communities emerged first as a boundary for Indian territory in 1808, and became Missouri's northern border 13 years later. Several contradictory surveys of the line led to disputes over local authority, exacerbated by the end of the 1830s as more settlers established homes and communities in the contested zone. For many, the disputes represented the antebellum debate between states' rights and federal power. By late 1839 the struggle between Iowa and Missouri erupted into a conflict characterized by two distinct phases. The first, punctuated by bombastic statements from politicians on both sides, was met with amusement by those living in the disputed region. But when this spat threatened to turn violent, the conflict entered its second phase, as borderland residents eventually took matters into their own hands and negotiated a settlement. Although tensions eased along the dividing line as the 1840s began, another decade would pass before the dispute saw a final resolution. Through it all, both Missourians and Iowans demonstrated a devotion to their boundary, which provided an invisible barrier against their competitors on the other side.

FEDERAL INTEREST in the Louisiana Purchase began shortly after the ink dried on the 1803 treaty. The Jefferson administration authorized several exploratory parties in the years that followed, most famously the one led by Meriwether Lewis and William Clark along the Missouri and Columbia rivers. Lewis and Clark's fame may have "kidnapped" attention to the purchase, but several other teams scouted the Red and Arkansas 
river valleys at the same time. ${ }^{3}$ Perhaps the least well-known voyage was led by Captain Zebulon M. Pike in late 1805 to determine the source of the Mississippi River. Although numerous expeditions from various nations had explored the upper Mississippi since the seventeenth century, and Indian agents and traders had already moved into the area, federal authorities wanted a more complete survey. In August 1805 Pike and about 20 soldiers and naturalists ascended the river from St. Louis. Their journey led past the future Missouri-Iowa borderland, in particular a feature in the Mississippi that Pike called "the rapids De Moyen," which would feature prominently in the dispute between the two political communities. The 11-mile-long stretch of rapids, located above the confluence of the Mississippi and Des Moines rivers, complicated travel with a plethora of shoals. For Pike's company, the rapids marked the start of the unknown, for "although no soul on board had passed them, we commenced ascending them, immediately." 4

Three years after Pike and his crew navigated the Des Moines rapids, and only five years after the United States took legal possession of Louisiana, the division between the future states of Missouri and Iowa began to take shape. In 1808 Meriwether Lewis, by then Missouri's territorial governor, treated with the Osage, a powerful American Indian group on the western frontier, to stabilize relations between the natives and the newcomers in his charge. Governor Lewis explained his desire for the meeting: "The establishment of a boundary has long been desirable, and the want of one, settled by treaty, has never ceased to create doubts, and sometimes embarrassments, of the most serious nature, in our courts of justice." 5 The Osage agreed to withdraw from all land between the Missouri and Arkansas

3. See Elliott West, "Lewis and Clark: Kidnappers," in A Whole Country in Commotion: The Louisiana Purchase and the American Southwest, ed. Patrick G. Williams, S. Charles Bolton, and Jeannie M. Whayne (Fayetteville, AR, 2005), 3-20.

4. Zebulon M. Pike, An Account of Expeditions to the Sources of the Mississippi, and through the Western Parts of Louisiana ... (Philadelphia, 1810), 4. The French explorer Père Jacques Marquette had christened the spot in 1673 by corrupting the name the Illinois used for their settlement near there. See The History of Van Buren County, Iowa (Chicago, 1878), 428-29, 4.

5. "The Osages," 11th Cong., 2nd sess., 3/14/1810, American State Papers 07, Indian Affairs, 1:766 (emphasis in original). 
rivers, and the Mississippi River and a geometric line approximately 30 miles east of the present western boundary of Missouri. They also surrendered any claims to land north of the Missouri River up to the present state line, reflecting the wide range of the Osage. ${ }^{6}$ In the years before efficient overland transportation, Lewis and others considered the inaccessible land far from good river access of minor importance, and focused their attention on securing control of the Missouri River valley first.

After the Osage treaty, another eight years passed before the area received significant attention. Following the War of 1812, however, the trans-Mississippi West was poised to experience rapid growth. To accommodate new settlers, the federal government needed to extinguish Indian title to ever more land and carve it up with the geometric policies it had used for several decades. In 1816 a government survey led by John C. Sullivan, in cooperation with the Osage, crafted an official barrier between Indian and American lands. Sullivan's team started at the confluence of the Missouri and Kansas rivers and proceeded due north for a hundred miles, then turned eastward and drew another line to the Des Moines River. ${ }^{7}$ The Osage had little claim to that land so far from their ancestral home on the Missouri River, but the 1808 treaty gave them the authority to help determine its future. As one of many such boundaries drawn between distant Indian and American territory in the early nineteenth century, the line initially received scant attention. But in the years to come, the work of Sullivan and the Osage would create controversies of both local and national proportions.

AS THE 1810s drew to a close and Missouri's promotion to statehood engendered fierce debate, the proposed state's boundaries evolved. ${ }^{8}$ After several proposals for a state both bigger and smaller than the one eventually created, Missourians approved their limits in an 1820 state constitution. The northern line was identified as

6. Ibid., 1/16/1810, American State Papers 07, Indian Affairs, 1:763.

7. "Boundary between Missouri and Iowa," 25th Cong., 3rd sess., 1/30/1839, H. Doc. 128, serial 347, 3.

8. See Milton D. Rafferty, Historical Atlas of Missouri (Norman, OK, 1982), 2. 
a meridian line passing through the middle of the mouth of the Kansas river, where the same empties into the Missouri river; thence from the point aforesaid north, along the said meridian line, to the intersection of the parallel of latitude which passes through the rapids of the river Des Moines, making the said line correspond with the Indian boundary line; thence east, from the point of intersection last aforesaid, along the said parallel of latitude, to the middle of the channel of the main fork of the said river Des Moines; thence down and along the middle of the main channel of the said river Des Moines to the mouth of the same, where it empties into the Mississippi River. ${ }^{9}$

The enforcement of political authority and property rights demanded such thoroughness in boundary definition. Thus when Missouri entered the Union in 1821, Sullivan's 1816 line marked its northern limit.

Following statehood, another three years passed with little attention to Missouri's northern boundary. In 1824, however, a new agreement between the federal government and native peoples of the upper Mississippi River valley brought notoriety to the area. The Ioway and the Sac and Fox nations, which dominated the upper Mississippi River near its confluence with the Rock, Des Moines, and Iowa rivers, consented to surrender their claims in Missouri. Separate agreements removed both groups from that state, referencing the Sullivan line once again as an Indian boundary as well as a political one. The Sac and Fox treaty also set aside a small parcel between the Mississippi and Des Moines rivers as a sanctuary for "half-breeds" of that group. ${ }^{10}$ Over the course of almost two decades, Missouri's northern boundary thus emerged primarily through treaties with Indian groups, adopted for the limit of that polity for simplicity's sake by federal and state politicians.

Shortly after the conclusion of these treaties, Missourians considered alterations to their northern frontier. The pressure to

9. Francis Newton Thorpe, The Federal and State Constitutions, Colonial Charters, and Other Organic Laws of the States, Territories, and Colonies Now or Heretofore Forming the United States of America, 7 vols. (Washington, DC, 1909), 4:2150-51.

10. "Treaties with the Ioway, Sac, and Fox Tribes," 18th Cong., 2nd sess., 12/15/ 1824, American State Papers 08, Indian Affairs, 2:525. See also "Proposition to Extinguish Indian Title to Lands in Missouri," 18th Cong., 1st sess., 5/14/1824, American State Papers 08, Indian Affairs, vol. 2. 


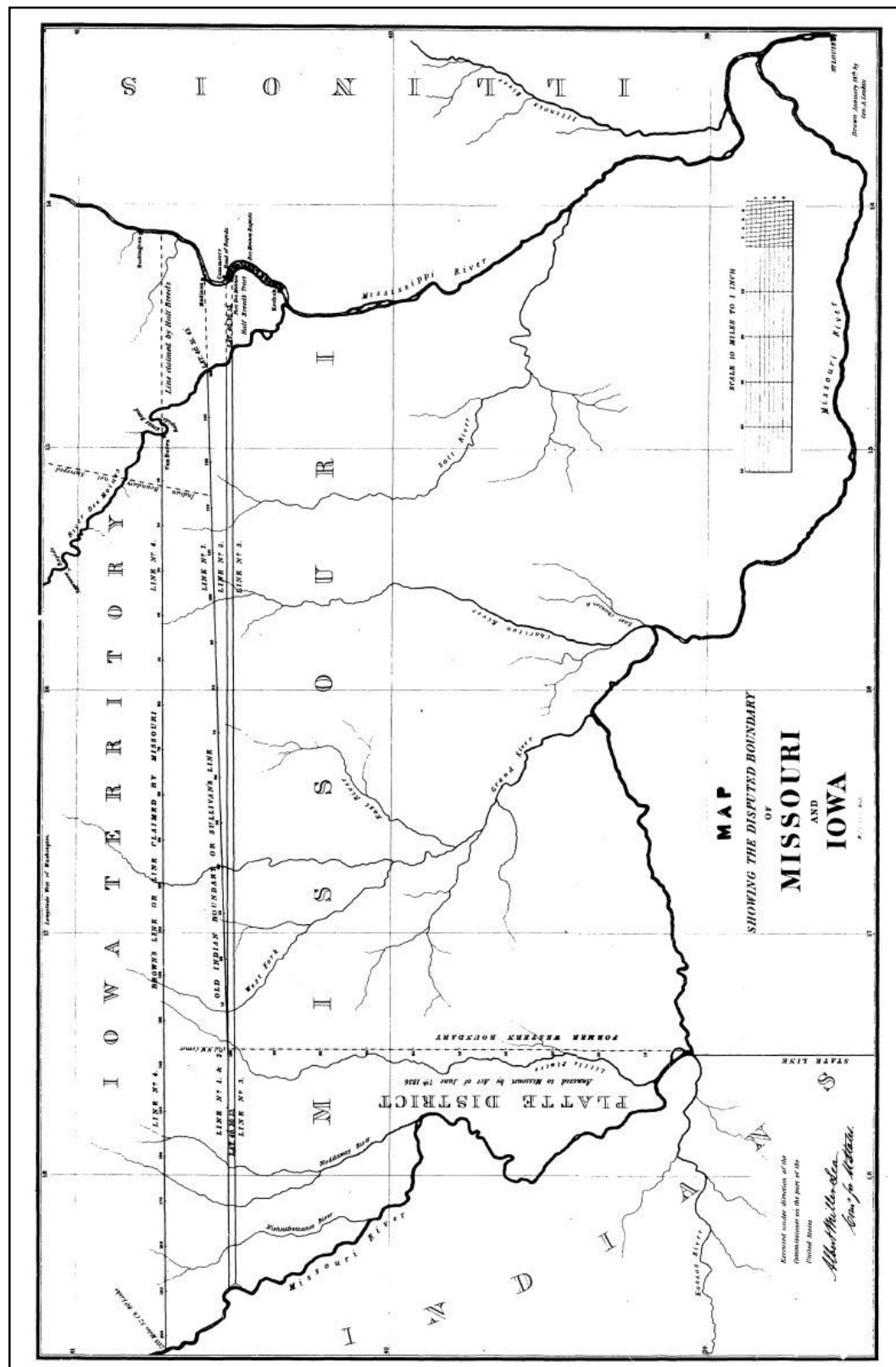

Map from the 1839 General Land Office report on the Missouri-Iowa Territory boundary dispute. The lines are, from north to south: Missouri's 1837 claim intersecting the Des Moines River rapids; the 1808 Osage treaty limit as missurveyed in 1816; the Osage line as it should have been marked; and a division intersecting the rapids in the Mississippi River. Note also the Platte Purchase (or "District") added to northwestern Missouri in 1836. From the U.S. Serial Set, "Boundary between Missouri and Iowa," 25th Cong., 3rd sess., 1/30/1839, H. Doc. 128, serial 347. 
annex a triangular parcel between the geometric western line and the Missouri River called the Platte Purchase was mirrored by interest in settling the northeastern corner of the state. By 1829 Missouri's legislature had begun petitioning Congress to annex the small "half-breed" tract defined in the 1824 Sac and Fox treaty. ${ }^{11}$ Technically, that tract did not belong to any Indian reserve, so Missouri considered it up for grabs. Their request fell on deaf ears. Two years later Missouri politicians offered an aesthetic reasoning for the addition: "It is a wedge in the corner of the State, disfiguring the form, and destroying the compactness, of our territory." 12 Apparently few Missourians recognized the coincidence of complaining about the northeastern notch when they had done the same to Arkansas through the "bootheel" in the early 1820s. The legislature went so far as to approve a constitutional amendment annexing the "half-breed" tract in 1835. ${ }^{13}$ Congress saw no pressing need to add the mixed-ethnicity denizens to the state, however, although they did acquiesce to the northwestern expansion of the Platte Purchase in 1836.14

With one of two alterations to their northern boundary approved, Missouri leaders wanted to better define the vaguely understood line. One St. Louis newspaper suggested that the line would intersect the Missouri River near the Council Bluffs, named after a meeting held there between the Lewis and Clark expedition and local American Indians in $1804 .{ }^{15}$ The bluffs ac-

11. "Memorial of the Legislature of Missouri, Praying that Improvements May Be Made in the Navigation of the Mississippi River; that an Alteration Be Made in the Northern Boundary Line of that State; and that Certain Indian Lands Be Purchased by the United States," 20th Cong., 2nd sess., S. Doc. 88, serial 182.

12. "Memorial of the General Assembly of Missouri, that the N. and N.W. Boundary May Be Enlarged, and a Mounted Force Granted for the Protection of the Frontier of the State, and its Trade with Mexico and the Indians," 21st Cong., 2nd sess., 2/28/1831, S. Doc. 71, serial 204, 4.

13. "Amendments - Constitution-Missouri," 23rd Cong., 2nd sess., 2/21/ 1835, H. Doc. 162, serial 274.

14. See "In the Senate of the United States," 23rd Cong., 1st sess., 4/8/1834, S. Doc. 263, serial 240, 2; "Northern Boundary of Missouri," 25th Cong., 2nd sess., 4/6/1838, H. Rep. 768, serial 335. Technically not part of an Indian reserve, the "half-breed" lands were opened to settlement in the late 1830s by both Wisconsin and Iowa territories. See Laws of Iowa, 1st Territorial Assembly, 1/24/1839, 224-25; ibid., 1/25/1839, 225; Burlington Hawk-Eye, 4/16/1846.

15. Missouri Argus, 2/17/1837. 
tually stood about 50 miles north of Missouri's line in the newly organized Wisconsin Territory, which then straddled the Mississippi River and extended into the modern Dakotas. Such uncertainty demanded better knowledge of the line's true position, particularly as American settlements gradually crept toward that part of the Louisiana Purchase. To that end, Missouri's legislature authorized a survey of the boundary, and invited the federal government and Wisconsin Territory to take part. ${ }^{16}$ When both declined, Missouri carried out the effort alone. According to the state constitution and several Indian treaties, "the parallel of latitude which passes through the rapids of the river Des Moines" served as the northern boundary, which to Missourians meant a series of shoals in that river. Unlike Sullivan's 1816 trek, which labored from west to east, the 1837 commission led by Joseph C. Brown started at a series of rapids at the Great Bend of the Des Moines River and proceeded westward. That created a new division anywhere from 10 to 15 miles farther north than Sullivan's boundary, the result of a surveying error that caused the latter line to run slightly north of east. ${ }^{17}$

The infant government of Wisconsin Territory disagreed with Missouri's new interpretation of the line, which carved a large slice of fertile land from its southwestern flank. Meeting in the new capital of Madison, the territorial legislature petitioned Congress to reaffirm the 1816 line. The legislators made the sensible suggestion that, since so little was known of the Des Moines River at the time of the 1808 Osage treaty, the rapids referenced in it must have been located elsewhere. The Wisconsinites suggested that "the lower rapids of the Mississippi, known, from the time of their first discovery by civilized man, as the Des Moines rapids, or rapids of the Des Moines river," were the proper termination point for the line. Territorial authorities also worried about the loss of free land to the slaveholding state south of the boundary. ${ }^{18}$

16. Laws of Missouri, 9th General Assembly, 1st sess., 12/21/1836, 26-28.

17. Missouri Argus, 8/23/1837.

18. "Proceedings of the Legislature of Wisconsin Territory, in Relation to the Boundary between that Territory and the State of Missouri," 25th Cong., 2nd sess., 1/2/1838, S. Doc. 63, serial 314. 
The dispute over which rapids were the ones referenced in treaties and legislation - those in the Mississippi or those in the Des Moines rivers - had simmered since at least 1831, but grew more acute by the end of the decade. ${ }^{19}$ The law passed by Missouri's General Assembly in 1837 to survey the line specifically mentioned the problem, directing the commissioners to explore the Des Moines River "to ascertain the true location of the rapids" upon which the line hinged. ${ }^{20}$ Wisconsin's legislature dropped the issue in 1838 when it persuaded Congress to organize a new territory from its land west of the Mississippi River. Wisconsin had become "too large and unwieldy for the perfect administration of prompt justice" and could not manage its rapidly growing western population. ${ }^{21}$ The task of settling the dispute with Missouri fell to the brand-new Iowa Territory and its politicians meeting at Burlington, a small Mississippi River town just north of the contested borderland.

THE NEW LEADERS of the Iowa Territory secured their own survey of the contentious boundary in 1838. Missouri declined to participate in the project, since it had completed one of its own the year before. The expedition, conducted by the General Land Office, eventually produced a detailed report by Albert Miller Lea in early 1839. It asked the essential question: "Where are those rapids?" 22

Lea identified four possible lines, all of which had some claim to legitimacy as the proper boundary, but which also all had their faults. Sullivan's 1816 line, for example, possessed the benefit of seniority over all others, but had been inaccurately surveyed and did not meet the mandated criteria of "a parallel of latitude." A straight line drawn from the northwest corner of Missouri (before the Platte Purchase), the second candidate for

19. "Memorial of the General Assembly of Missouri," 2/28/1831, 3.

20. Laws of Missouri, 12/21/1836, 27.

21. "Iowa Territory," 25th Cong., 2nd sess., 2/6/1838, H. Rep. 585, serial 334. No mention of the dispute over the new Iowa territory's southern boundary appeared in its organic act. See Laws of Iowa, 1st Territorial Assembly, 6/12/ $1838,31-40$.

22. "Boundary between Missouri and Iowa," 25th Cong., 3rd sess., 1/30/1839, H. Doc. 128, serial 347, 11-12, 5; Missouri Courier, 12/1/1838. 
the proper division, did not intersect any rapids on its eastern end. The other two boundaries suggested by Lea crossed through rapids in the Mississippi and Des Moines rivers, respectively, either of which he considered legally permissible considering the vagueness of the phrase "the rapids of the Des Moines river." Lea included several letters from knowledgeable persons, including lawyers, surveyors, and even explorer/politician/Indian superintendent William Clark, offering contradictory opinions about which rapids the laws and treaties had intended to anchor the line. Instead of clearing up the confusion, Lea's report only added to it. ${ }^{23}$

If the region surrounding the boundary between Missouri and Iowa Territory had remained vacant and inconsequential, as the first planners of the Louisiana Purchase boundaries had expected, the controversy might have remained an academic one. But an influx of American settlers to the region in the 1830s complicated matters, and made the need to establish a clear division much more acute. The Black Hawk War of the early 1830s led to the removal of the Sauk and Meskwaki west of the Mississippi River, and the U.S. Army established Fort Des Moines in the "Half-breed Tract" in 1834 to keep the peace between Indians and American settlers. ${ }^{24}$ Within three years "a torrent of immigration ... poured into this Western Paradise," in the words of contemporary booster John Plumbe Jr. Plumbe rhapsodized about the prospects of the upper Mississippi valley, comparing it to "a beauteous and fascinating female, whose transcendant [sic] attractions must be seen, to be appreciated." By 1839, estimates of Iowa Territory's population ranged as

23. Ibid., 7-10, 16-24. Missouri's 1837 survey corresponded to the fourth line described by Lea, the one passing through the rapids in the Des Moines River, about a dozen miles north of the other boundaries. The Missouri legislature approved a law in 1839 that reinforced its claim to the 1837 line as the state's official northern border. See Laws of Missouri, 10th General Assembly, 1st sess., 2/11/1839, 14. See also Territorial Gazette and Burlington Advertiser, 3/2/1839; and Missouri Republican, 3/14/1839.

24. See Robert W. Frazer, Forts of the West: Military Forts and Presidios and Posts Commonly Called Forts West of the Mississippi River to 1898 (Norman, OK, 1972), 48-49; and Missouri Republican, 8/31/1839. For recent narratives of the Black Hawk War, see Kerry A. Trask, Black Hawk: The Battle for the Heart of America (New York, 2006); and Patrick J. Jung, The Black Hawk War of 1832 (Norman, OK, 2007). 
high as 30,000, explaining Wisconsin's willingness to turn the distant region into its own polity. ${ }^{25}$

Much of the early settlement in Iowa Territory focused along the Mississippi River, but by the late 1830s the lower Des Moines River in the southeastern part of the territory had become a favored destination. The Wisconsin territorial legislature had created the immense Van Buren County, which would figure prominently in the ongoing boundary dispute with Missouri, along the territorial boundary in 1836. In the years to come, Iowa politicians gradually pared down the county named after then Vice President Martin Van Buren. Within the next three years a series of small towns appeared along the banks of the Des Moines, which bisected the county from northwest to southeast. These towns included Bonaparte, Rochester, Vernon, and Watertown, established in 1837; Iowaville, in 1838; and Birmingham, Farmington, Keosauqua, Kilbourne, and Pittsburg, in 1839. Territorial officials asked for money from Washington, D.C., to build a road connecting these new towns in late 1839. The federal government fueled more growth by opening up even more land in southern Iowa Territory in the summer of 1839 for farms, timber works, and stone quarries. A diverse population rapidly moved in, as one resident described for a Missouri newspaper.

The whole Territory is now full of strangers. Our city [Burlington] has become a perfect Gotham - as emigrants from every State and in fact from every civilized country on the Globe are flocking in crowds to our place. Here is the staid and phlegmatic Germanthe enterprising and industrious New Englander - the ardent and chivalrous Kentuckian - the hospitable and accomplished Virginian, the persevering and energetic Ohion [sic] and Hoosier, all congregating upon our shores and each furnishing his quota of the future character as well as prosperity of our Territory. ${ }^{26}$

Van Buren County town-builders of the late 1830s encountered a unique group of Americans already living there, a group

25. John Plumbe Jr., Sketches of Iowa and Wisconsin, Embodying the Experience of a Residence of Three Years in Those Territories (Iowa City, 1948), 2, 3, 101 (emphasis in original).

26. Ibid., 57, 100; History of Van Buren County, 361-62, 467-509; Laws of Iowa, 2nd Territorial Assembly, 12/31/1839, 150-51; Missouri Argus, 8/13/1839; Missouri Republican, 10/28/1839 (emphasis in original). 
that well demonstrated the complexity of life along this borderland. A squatter society had arrived shortly after the Black Hawk War in search of "freedom from the restraints imposed by the morality, the religion, the industrious habits and the taxing propensities of the old States." Nicknamed the "Hairy Nation" for their unkempt appearance, these residents cared little about the boundary dispute. Instead, laden with ballots and booze, members of this hirsute society would "exercise their undoubted and undisputed right of sovereignty" in Missouri and Wisconsin and Iowa territories at the same time, and dined in their humble homes with politicians from both sides. Dwellers in the "Hairy Nation" also paid no taxes, as they could always claim to answer to the opposing jurisdiction depending on which collector appeared at their doorstep. ${ }^{27}$ Still, although some saw the uncertain authority along the boundary as an opportunity, others demanded action to clear up the confusion. And the more settlers who moved into the area, the greater the need became to clarify the boundary for purposes of taxation, suffrage, judicial authority, and other issues.

Newspapers on both sides of the line spilled ink over the contentious issue in the summer of 1839. Asserting Missouri's rights as an independent republic within the larger Union, the Missouri Republican of St. Louis argued that neither Congress nor Iowa's leadership possessed the authority to alter Missouri's boundaries. ${ }^{28}$ Indeed, in 1839 the Missouri legislature had approved two laws in that spirit that further complicated matters. It first created Clark County in the northeastern corner of the state, at the confluence of the Des Moines and Mississippi rivers. Carved appropriately enough from the northern reaches of Lewis County, Clark County by law extended north to the boundary surveyed in 1837, beyond the 1816 line. The assembly also approved legislation that reasserted the state's northern limit as the one surveyed in 1837. Meanwhile, Iowa's Territorial Gazette and Burlington Advertiser pledged that Iowans would stand firm against any threat to land they claimed as their own, regardless of their territorial youth. Still, the Burlington news-

27. Western Gazette, 5/13/1854.

28. Missouri Republican, 7/30/1839. 
paper worried that "the controversy between this Territory and the State of Missouri is beginning to wear a serious aspect." 29

As the press fanned the flames, pressure increased on politicians in Burlington and Jefferson City, the governors in particular. The chief executives of Missouri and Iowa Territory were no strangers to confrontation, and both had recently demonstrated a willingness to use force to get their way. To the south of the line, Governor Lilburn W. Boggs had engaged in a war of extermination against Mormons living in Missouri in 1838. Responding to threats of religious disfranchisement, a faction within the church had attacked non-Mormon settlements; in response Governor Boggs ordered the state militia to kill or run off every Latter-day Saint in the state. His campaign forced the Mormons across the Mississippi River into Illinois, where they reestablished themselves at Nauvoo. ${ }^{30}$ Boggs would prove just as willing to defend his state from "foreign" invasion as from religious insurrection.

Boggs's counterpart to the north, Robert Lucas, had been appointed by President Van Buren in 1838 as the first governor of Iowa Territory. Well experienced for such a role, Governor Lucas had served as the chief executive of Ohio from 1832 to 1836. Late in his Ohio term Lucas had ordered the state militia to the northwestern frontier in a dispute with Michigan Territory over land along the Maumee River. Several hundred troops squared off near the present city of Toledo, Ohio, in 1835, until the federal government intervened. With the help of President Andrew Jackson, a fellow Democrat, Lucas retained the narrow territory called the "Toledo Strip" for his state. Four years later, when faced with a similar situation in Iowa, Lucas also acted in a forceful way. This time, though, as the governor of a young territory challenging the claims of a powerful state, he found himself in a political position opposite to the one he had faced in Ohio. ${ }^{31}$

29. Territorial Gazette and Burlington Advertiser, quoted in Missouri Republican, 5/22/1839 and in Missouri Whig and General Advertiser, 8/10/1839.

30. For a history of Governor Boggs's extermination campaign, see Stephen C. LeSueur, The 1838 Mormon War in Missouri (Columbia, MO, 1987).

31. See Willard V. Way, The Facts and Historical Events of the Toledo War of 1835 (Toledo, 1869); and Peter S. Onuf, Statehood and Union: A History of the Northwest Ordinance (Bloomington, IN, 1987), 94-108. 
THE MOST SERIOUS TENSIONS between Missouri and Iowa over their shared boundary took place in two distinct phases in the second half of 1839. The first consisted primarily of a heated exchange between Governors Boggs and Lucas in the local newspapers. In what one historian aptly calls "the merry war of proclamations," the two officials traded threats over land they both believed was theirs. ${ }^{32}$ Lucas, the man with the most experience in such matters, fired the opening salvo in this semantic struggle. In early August 1839 newspapers printed a statement issued by the governor challenging what he considered Missouri's attempt to "obtain a surreptitious jurisdiction" over a sliver of his territory. Lucas insisted that only through judicial action could the matter reach a suitable settlement, and he admonished territorial residents not to fraternize with Missouri officials. The governor also noted that, if necessary, he would appeal to President Van Buren for assistance against Missouri's creeping authority. ${ }^{33}$

Several weeks after Governor Lucas's proclamation, Governor Boggs shot back with his own. The Missouri executive declared that he would defend his state's integrity as defined by the 1837 boundary. Boggs also pledged to send the state militia to help Clark County officials compel payment of taxes in the disputed zone. Emphasizing his state's rights within the federal system, Boggs identified the United States as the real second party to the dispute, since the national government held Iowa Territory in trust until it joined the Union. In doing so, he attempted to reduce Lucas to a nonentity, and place the dispute in the hands of officials in Washington, D.C. The governor also expressed regret that "a people whose language, habits, pursuits and principles are the same, and whose mutual interest prompts them to be neighbors in sentiment as well as locality," should find themselves in this increasingly resentful situation. ${ }^{34}$ Many Missouri newspapers, such as the Republican of St. Louis,

32. Charles S. Larzelere, "Notes and Documents: The Iowa-Missouri Disputed Boundary," Mississippi Valley Historical Review 3 (1916), 80.

33. "Message from the President of the United States, in Relation to the Disputed Boundary Line between the State of Missouri and Territory of Iowa," 26th Cong., 1st sess., 12/24/1839, S. Doc. 4, 3-5; Missouri Republican, 8/15/1839.

34. Missouri Whig and General Advertiser, 9/7/1839. See also Missouri Republican, 8/30/1839. 
expected the state to rally behind the firm stance of their governor in defense of their claimed territory. ${ }^{35}$

A month later, Governor Lucas fired off another lengthy missive, referencing several points made by Governor Boggs. Lucas expressed dismay that Boggs had adopted a militaristic attitude, but took the opportunity to adopt just such an attitude himself. Using Boggs's own logic, Lucas warned that the Missouri militia would not only be trespassing on Iowa Territory but essentially declaring war on the federal government, which retained ultimate jurisdiction north of the state line. The territorial governor also spoke directly to his charges living in the disputed part of Van Buren County, asking them to "be calm and discreet in all your acts." He went on:

Look up to the civil authorities of the United States for your protection. Should you even be threatened with extermination by the all powerful arms of Missouri, be not dismayed. You are neither slaves that you should pay tribute to a foreign government, nor passive members of a defenceless community, that you should be taxed without your consent. You occupy the exalted station of free and independent citizens of the United States.... [Y] ou may rest assured, that should the President of the United States authorize us to repel force by force, should our territory be invaded, it will be promptly done, regardless of the boasted prowess and superior numbers of the Missouri militia. ${ }^{36}$

By hinting at the free soil of Iowa Territory as contrasted with slaveholding Missouri, as well as Boggs's brutality against the Mormons several years earlier, "Headstrong Bob" Lucas added fuel to the fire. ${ }^{37}$

While the executives traded insults in the popular press, most residents of Missouri and Iowa viewed the dispute as a comic one. The Missouri Republican thought that it "would be well if Governor[s] Boggs and Lucas can arrange this matter by a newspaper war." 38 The most famous incident of the entire conflict took place during this executive exchange, when a Missourian

35. Missouri Republican, 8/31/1839.

36. Ibid., 10/8/1839 (emphasis in original).

37. Ibid., $9 / 30 / 1839$.

38. Ibid. 
cut down several hollow trees used as beehives by settlers who claimed allegiance to Iowa Territory. Tried in absentia, the vandal was fined $\$ 1.50 .39$ This story provided a moniker for the entire conflict, the "Honey War." It also inspired a Missouri wag to pen a satirical poem, poking fun at the governors in particular, and calling for a sensible solution.

Now in conventions let us meet,

In peace this thing to settle,

Let not the tiger's war-like words

Now raise too high our metal [sic].

Why shed our brother's blood in haste,

Because big men require it?

Be not in haste our blood to waste,

No prudent man desires it. ...

Now if the Governors want to fight,

Just let them meet in person,

For Governor Boggs can Lucas flog,

And teach the brag a lesson....

And then no widows will be made,

No orphans unprotected,

Old Lucas will be nicely flogg'd,

And from our line ejected. ${ }^{40}$

Not everyone considered the controversy as serious as the leaders in Jefferson City and Burlington did. But an incident in the borderland around the time the poem hit the press transformed the Missouri-Iowa conflict into something much more worrisome to many on both sides of the vague line, and in particular to those living nearest to it.

THE SECOND PHASE of the 1839 boundary dispute began on October 24, when Sheriff Uriah S. Gregory and several militiamen from Clark County, Missouri, met with officials from Van Buren County, Iowa, including its sheriff, Henry Heffleman. Sheriff Gregory insisted on his authority to collect taxes from those living south of the 1837 boundary. The meeting escalated with "several warm speeches on both sides; amounting almost

39. Duane Meyer, The Heritage of Missouri - A History (St. Louis, 1973), 185.

40. Missouri Whig and General Advertiser, 10/26/1839. 
to a declaration of war." When the news reached Jefferson City several days later, Boggs ordered the state militia to support Gregory in carrying out his lawful duties. The Missouri Argus cautioned all involved to "consider the advantages of peace over discord," but the stands taken by the executives of both states in their proclamations promised the use of weapons rather than words. ${ }^{41}$

Two days after the tense exchange between Sheriffs Gregory and Heffleman, residents of the borderland attempted to solve the problem themselves. Delegates from Clark and Van Buren counties - including private citizens and local militia officers - met in Monticello, Missouri, about 40 miles south of the disputed territory. After pledging friendship to their neighbors, the Missourians proposed to share jurisdiction until the federal government could sort out the matter. In response, the Iowans stated that they could not accept concurrent authority, but would generously agree to both sides suspending tax collection for the time being. Upset at the rejection of their proposal, the Missourians drafted a resolution calling for Sheriff Gregory to "proceed to a more energetic discharge of his civil duties" and dismissed their counterparts to the north. Shortly thereafter, the adjutant general of Iowa's territorial militia reported to Governor Lucas that the conference had only aroused passions on both sides. ${ }^{42}$ For reasons of legality and pride, neither side was willing to compromise with the other, from the governors on down to those living in the discordant region.

With the backing of his constituents, Sheriff Gregory proceeded into northern Clark County-or perhaps southern Van Buren County - in mid-October 1839 to collect taxes from the settlers there. Gregory encountered four people, two of whom refused to pay, and he reportedly "molested their property." Before Sheriff Heffleman could respond, Gregory returned to the safety of the Clark County seat at Waterloo, in undisputed Missouri land. Governor Lucas wrote a letter of support to Hef-

41. Missouri Argus, 11/1/1839, 11/23/1839; Missouri Republican, 11/7/1839. See also History of Van Buren County, 365.

42. Missouri Whig and General Advertiser, 11/9/1839. See also "BoundaryMissouri and Iowa," 26th Cong., 1st sess., 12/31/1839, H. Ex. Doc. 36, serial $364,5-8,10-12$. 
fleman, expecting him to "be as prompt and vigilant in enforcing the laws and protecting the citizens of the United States within this Territory, as those of Missouri possibly can be, in their intrusions upon our neighbors." 43 For the next few weeks the situation calmed, though, as both sides considered their next move. ${ }^{4}$

More than a month after his first attempt, Sheriff Gregory returned to tax the borderland on November 19, and Sheriff Heffleman quickly tracked him down. Governor Lucas happily received the news and bestowed on Heffleman "the approbation of every citizen of Iowa." A local court put Gregory on trial for exercising an illegal jurisdiction and jailed him at the county seat in Farmington. When word of the arrest reached Missouri's militia officers, they immediately dispatched a brigade to prepare state defenses, and mustered four additional divisions in the northeastern counties. Shortly thereafter, 40 troops headed north, intending to break Gregory out of jail. Rumors of a large force under Heffleman's command worried the Missourians, though, so the militia officers proceeded to Farmington alone to attempt a negotiated settlement. The Iowans rebuffed them, and the officers returned to Waterloo to await reinforcements. In the meantime Gregory was transferred to another jail farther away from the disputed boundary. 45

The potential for bloodshed over the boundary dispute increased with each passing day, much to the concern of many people on both sides of the line. As the Missouri Republican observed, "It is every way probable that a collision will ensue, as the excitement is becoming very intense and gradually extending over a much larger portion of the people of the state and territory." 46 Governor Lucas wrote to Secretary of State John Forsyth, expressing his concern. "I am apprehensive that blood will be shed; and if blood begins to flow, it is impossible to foretell where the matter will end." Iowa's territorial legislature memorialized Congress for help, asking protection for "that which

43. "Boundary-Missouri and Iowa," 12/31/1839, 3, 4.

44. Missouri Republican, 11/12/1839.

45. "Boundary - Missouri and Iowa," 12/31/1839, 14; Missouri Whig and General Advertiser, 11/30/1839; Missouri Republican, 12/5/1839, 12/ 7/1839.

46. Missouri Republican, 12/ 7/1839, 12/4/1839. 
our stronger sister is attempting to wrest from us by force." 47 Neither side wanted to be the first to back down, but both wanted to avoid violence if possible.

The seriousness of the situation contrasted markedly with the appearance of the soldiers marching toward the front lines. Both Missouri and Iowa militiamen struck many observers as a humble, perhaps even laughable, bunch. About 800 Missourians mustered in the camp near Waterloo in every conceivable uniform. Those who did appear resented the state's expectation that they would supply themselves, and they looted a store in LaGrange for food and blankets. While heading upriver toward Iowa Territory, the Missourians also captured supplies, and even blocked the mail from reaching their enemy. ${ }^{48}$ With overland transport still a rudimentary process, Missouri's long riverine frontage enabled it to directly affect Iowa's ability to make war.

Iowa's troops, numbering upwards of 600 , found conditions much the same as Missouri's. Farmington struck one observer as "a military camp, and the streets a place for military parade." Armed with everything from muskets and pitchforks to hoes and spears, from scythes and clubs to "an old fashioned sausage stuffer," the Iowans also had to fend for themselves logistically, to which they also objected. One militiaman sarcastically remembered, "We were willing to shed our blood for our beloved Territory and, if necessary, to kill a few hundred Missourians, but we were not going to do that and board ourselves besides." Nonetheless, they raised the rallying cry, "Death to the Invading Pukes!" in reference to Missouri's nineteenth-century nickname of convoluted origin. But the cold and snow of the coming winter was the worst enemy of the ill-supplied forces of both sides. ${ }^{49}$

47. “Boundary - Missouri and Iowa," 12/31/1839, 3, 20.

48. Ibid., 15. See also Meyer, Heritage of Missouri, 183; and Kraus, "A Study in Border Controversy," 93.

49. "Boundary - Iowa and Missouri," 26th Cong., 1st sess., 2/12/1840, H. Ex. Doc. 97, serial 365, 3; Eric McKinley Erickson, "The Honey War," Palimpsest 6 (1924), 346-48; Burrows, "Rumors of War," 72. George Earle Shankle, American Nicknames: Their Origin and Significance (New York, 1937), 355, cites two explanations for the "puke" moniker. The most likely story comes from northern Illinois in the 1820s, when Missourians flocked to the Galena lead mines in such great numbers that "those already there declared the State of Missouri had taken a 'puke.' " 
As 1839 drew to a close, many residents of northern Missouri and southern Iowa concluded that the pseudo-war must stop. At a hastily called mass meeting, Marion County, Missouri, dweller Thomas L. Anderson expressed the sentiments of many as he described the plight of both militias.

Send them home to their families. Send them home to those who at this inclement season need them, and who are watching anxiously for them, and praying for their safe and speedy return. And in the name of the God of Mercy and Justice, gentlemen, let this monumental piece of absurdity, this phenomenal but cruel blundering have an end. 50

Anderson and other residents of Marion County, seated at Palmyra about 60 miles down the Mississippi River from the borderland, circumvented the military conflict and political posturing in a desperate effort to restore peace. On December 9 the Marion County committee drafted a resolution demanding an immediate end to all hostile actions, and called for a federal solution to the crisis. Three days later officials in Clark County seconded the document, and on December 14 it received the support of the Iowa territorial legislature. In poignant words the assembly unanimously resolved that "if that much to be deplored time should come when we shall be required to shed the blood of each other, we here pledge ourselves collectively and individually to endeavor by every means in our power to allay the horrors and calamities of the civil war." 51 Incarcerated Sheriff Gregory was released, and territorial courts eventually dropped the charges against him. ${ }^{52}$

50. Quoted in Walter B. Stevens, Centennial History of Missouri (The Center State): One Hundred Years in the Union, 1820-1921 (Chicago, 1921), 65.

51. Missouri Whig and General Advertiser, 12/14/1839, 12/21/1839; Missouri Republican, 12/17/1839. See also "Memorial of the Legislative Assembly of the Territory of Iowa, praying the adjustment of the boundary line between that Territory and the State of Missouri," 26th Cong., 1st sess., 1/8/1840, S. Doc. 53, serial 355; and Daily National Intelligencer, 12/30/1839.

52. Hawkeye and Iowa Patriot, 11/12/1840. Missouri's legislature appropriated $\$ 1,500$ to Sheriff Gregory in early 1841 to compensate for legal expenses incurred as he brought suit against the Van Buren County officials who had arrested him. See Laws of Missouri, 11th General Assembly, 1st sess., 2/16/1841; Negus, "The Southern Boundary of Iowa," 749-50. 
A diverse reaction to this sudden peace came just as swiftly. A committee of concerned Missourians from Lewis County, located between Clark and Marion counties, spoke out strongly against the perceived surrender to Iowa. ${ }^{53}$ Meanwhile, families criticized both Governors Boggs and Lucas in the press for sending their fathers, brothers, and sons out into the cold for a week to fulfill the bombastic pledges the governors had made months earlier. ${ }^{54}$ An Iowa Sun reader wrote,

The two governors instead of having the question settled by an amicable suit at law, as two neighbors who had a dispute about the dividing line between their plantations would do, have made all this bustle and incurred this enormous expense on their respective governments. To what strange infatuation is this conduct to be attributed? Are these men in their sober senses? Or have they become so valorous, that nothing but fight will satisfy their stomachs? Mr. Lucas, while governor of Ohio, immortalized himself, by a similar quarrel with the governor of Michigan, and Governor Boggs, has recently won imperishable honors, and never fading laurels in the war with the Mormons. . . . It is therefore perhaps not to be wondered at, that these two renowned chieftains, being placed in command so near each other, should, like two mighty ram goats, feel a desire to knock horns together, and make a noise in the world. 55

But the most graphic reaction came from the frostbitten militiamen themselves, as one vividly described.

About the time we got our fires burning, we received information that we would be turned home. . . . However, being determined to have our sport, we retired a short distance outside of the old Colonel's blazed encampment, taking with us a quarter of venison that we had the good luck to kill on the way, which we severed in two pieces, and hung up, in representation of the two Governors, and fired a few rounds at them, until we consid-

53. Missouri Whig and General Advertiser, 12/21/1839, 1/18/1840, 1/25/1840.

54. Ibid., 1/4/1840.

55. Iowa Sun (Davenport), 12/18/1839, quoted in Thomas M. Spencer, “'Demand Nothing but what is Strictly Right and Submit to Nothing that is Wrong': Governor Lilburn Boggs, Governor Robert Lucas, and the Honey War of 1839," Missouri Historical Review 103 (2008), 35-36. Spencer focuses on the military aspect of the state boundary feud and lays the blame for the conflict squarely at the feet of Missouri's chief executive. 
ered them dead! dead!! They were then taken down, and borne off by two men to each Governor, enclosed in a hollow square, with the muffled drum, and marched to the place of interment, where they were interred by the honors of war. We fired over their graves, and then returned to the encampment. ${ }^{56}$

No group appreciated the end of the farcical conflict more than those who had been expected to fight it out. Although neither Boggs nor Lucas approved of the extralegal decision, and released resolutions expressing their dismay, they no longer enjoyed enough popular support to maintain troops on the boundary. 57

WITH THE DAWNING OF THE 1840s, peace at last returned to the Missouri-Iowa borderland. Still, the debate over which line marked the proper boundary between the two demanded settling. Federal politicians, awakened to the matter through reports trickling eastward throughout the latter months of 1839, took up the matter in early 1840. Senator Lewis F. Linn of Missouri spoke in Congress with sympathy for both sides, and asked his colleagues to help resolve the matter. The House of Representatives debated a bill that would reaffirm the 1816 line as the official northern boundary of Missouri, a notion that met with scorn when Missouri newspapers printed it in the late weeks of winter. Whig party newspapers in particular used the bill as an example of the incompetence of Democratic officers, including Senators Linn and Thomas Hart Benton. Although he also disapproved of the bill, Governor Boggs, a fellow Democrat, reminded his constituents that with Iowa's continually growing population and its expected statehood, the federal government needed to mediate between the two parties sooner rather than later. 58

56. Missouri Whig and General Advertiser, 12/21/1839.

57. Missouri Whig and General Advertiser, 1/4/1840. See also Missouri Republican, 2/25/1840; and Missouri Whig and General Advertiser, 11/28/1840.

58. Congressional Globe, 26th Cong., 1st sess., 1/10/1840, 110-12; "Boundary of Missouri and Iowa," 26th Cong., 1st sess., 2/4/1840, H. Rep. 2, serial 370; Missouri Whig and General Advertiser, 2/29/1840, 3/14/1840; Territorial Gazette and Burlington Advertiser, 12/5/1840. 
Another issue of concern to both Missouri and Iowa Territory involved their almost-defenders. Members of both militias requested reimbursement for expenses incurred during the several weeks of preparation for war. Missouri's state legislature made appropriations in early 1841 for the troops sent to the northern frontier as well as for those who took part in the Mormon campaign. ${ }^{59}$ Because Iowa was a territory, however, its leadership expected the federal government to pay its bills. Secretary of War Joel R. Poinsett stated that, since he had not approved the use of the territorial militia, he saw no reason for Congress to pay for its little adventure. The House of Representatives nonetheless requested Iowa's muster rolls, which militia officers compiled in the late summer of 1840 . Eventually the legislative branch decided not to pay Iowa's militia for a campaign the War Department had not authorized. The territory and state continued to petition Congress to change its mind for the next 15 years, but were ultimately unsuccessful. 60

In the winter of 1840-41, both Missouri and Iowa Territory experienced a change of political leadership. Thomas Reynolds won an election to succeed Governor Boggs in Jefferson City in the waning months of 1840 . And in the spring of 1841 a new Whig administration in the White House replaced Democratic Governor Lucas with John Chambers. With both political communities under new management, their approach to the boundary dispute changed as well. 61

59. Laws of Missouri, 11th General Assembly, 1st sess., 2/16/1841, 106-7.

60. “Iowa Militia," 26th Cong., 1st sess., 3/6/1840, H. Doc. 123, serial 365; "Iowa Militia Claim," 26th Cong., 1st sess., 5/25/1840, H. Rep. 543, serial 372; Territorial Gazette and Burlington Advertiser, 8/8/1840, 3/27/1841; "IowaExpenses Southern Boundary," 27th Cong., 2nd sess., 2/12/1842, H. Doc. 84, serial 402; "Pay of Iowa Militia," 27th Cong., 2nd sess., 7/4/1842, H. Rep. 896, serial 410; Congressional Globe, 27th Cong., 3rd sess., 2/20/1843, 311; "Iowa Militia," 28th Cong., 1st sess., 3/28/1844, H. Rep. 371, serial 446; "Iowa Militia," 28th Cong., 2nd sess., 1/31/1845, H. Rep. 88, serial 468; Congressional Globe, 28th Cong., 2nd sess., 2/10/1845, 268; "Iowa Militia," 29th Cong., 1st sess., 5/19/1846, H. Rep. 678, serial 490; Congressional Globe, 29th Cong., 1st sess., 6/9/1846, 949; "Pay for Militia - Called Out by U.S. Marshal," 33rd Cong., 2nd sess., 2/20/1855, H. Misc. Doc. 31, serial 807.

61. Regardless of the controversies surrounding Governor Lucas's tenure, the Territorial Gazette and Burlington Advertiser, 4/17/1841, printed a flowery farewell and thanked him profusely for his services as the first territorial executive. 
For the first time in four years, Missouri proposed cooperation with federal authorities to "finally and peaceably" mark the line. In a plan drawn up by the legislature in late 1840, surveyors approved by the state senate and Congress would work jointly. In the meantime, county officials would desist from levying taxes on inhabitants of the disputed territory. ${ }^{62}$ Iowa demanded its own voice on the project to defend local interests, but Missouri argued that the territory's needs would be represented by a federal surveyor, and the idea fizzled. ${ }^{63}$

Congress resumed consideration of this festering issue a year later. Of particular concern in 1842 was the perennial debate about which rapids - in or of the Des Moines Riveranchored the eastern end of the boundary. Army Corps of Engineers surveys of the Des Moines River in 1840 and 1841 had reported numerous obstacles that could be considered rapids in that flow. ${ }^{64}$ Missouri's secretary of state forwarded more than a dozen letters from individuals affiliated with the 1816 survey and the 1820 constitutional convention, all of which insisted on rapids in the Des Moines River. ${ }^{65}$ But members of a House committee assigned to investigate the matter disagreed. They believed that the better-known Des Moines rapids in the Mississippi River must have been the ones intended to shape the line instead of a political division drawn through "an unknown and unbroken forest, inhabited by and belonging to the savage, and on some one of twelve ripples." 66 The notion that the federal

62. Laws of Missouri, 11th General Assembly, 1st sess., 12/19/1840, 23-24, 127-28. See also "Letter from the Governor of Missouri, Transmitting an Act of the General Assembly of the State of Missouri for Ascertaining and Settling the Northern Boundary Line of that State; Together with a Memorial of the Legislature of Said State on the Same Subject," 26th Cong., 2nd sess., 1/5/1841, S. Doc. 40, serial 376.

63. Hawkeye and Iowa Patriot, 3/4/1841, 3/11/1841. See also Territorial Gazette and Burlington Advertiser, 3/27/1841, 5/1/1841. Missouri's legislature passed a similar bill in early 1843, but again Congress took no action. "Boundary with Iowa," 28th Cong., 1st sess., 12/22/1843, H. Doc. 26, serial 441.

64. "Northern Boundary of Missouri," 27th Cong., 3rd sess., 12/31/1842, H. Doc. 38, serial 420, 13-20.

65. "Northern Boundary of Missouri," 27th Cong., 2nd sess., 1/20/1842, H. Doc. 48, serial 402; "Northern Boundary of Missouri," 27th Cong., 3rd sess., 2/11/1843, H. Doc. 138, serial 421.

66. "Boundary between Missouri and Iowa," 27th Cong., 2nd sess., 5/26/1842, H. Rep. 791, serial 410, 11 (italics in original). 
government might have been vague when defining the limits of future members of the Union did not seem possible to the House in 1842, although history often contradicted that view.

When the House of Representatives debated a bill to define the border in the summer of 1842, member John C. Edwards of Missouri objected on the grounds of states' rights. He suggested that because Iowa was still a territory he feared that the federal government would try to use its authority to unconstitutionally alter the shape of Missouri. Edwards claimed for his state the approximately 2,600 square miles in dispute. Iowa, he said, "has ample territory, and enough to spare for two more states." In reply, other congressmen pointed out that Missouri was already the largest member of the Union. Edwards nonetheless continued, "Iowa is encroaching upon us, and grasping part of our territory; and the United States, like all tender mothers, is taking sides with her infant child against the older one, in sustaining her groundless pretensions." Iowa's delegate, Augustus C. Dodge, suggested that Edwards used the tricks of his legal training to unjustly portray his own state as the victim. Dodge pointed the finger instead at "gigantic, avaricious, grasping Missouri." 67 The dispute inspired many politicians to trade accusations, whether across the line itself or across the House chamber.

As the rapidly increasing population of Iowa Territory made statehood ever more likely in the early 1840s, the boundary issue remained a problem forever in need of resolution. Meeting in the new capital of Iowa City in the fall of 1844, delegates discussed defining the southern line as "up the Des Moines to the old Indian Boundary line or North line of Missouri," which could be interpreted as either the 1816 or 1837 limit. Eventually they settled on a boundary up the Des Moines River "to a point where it is intersected by the old Indian boundary line, or line run by John C. Sullivan in 1816." When Missouri politicians heard of the proposal, they complained to Washington, D.C., that Iowa was trying to cleave off part of their state. ${ }^{68}$

67. Congressional Globe, 27th Cong., 2nd sess., 7/20/1842, 770-71; Appendix to the Congressional Globe, 27th Cong., 2nd sess., 7/20/1842, 248, 945.

68. Burlington Hawk-Eye, 10/17/1844; "Memorial of the General Assembly of Missouri, Praying that the Southern Boundary Line of the Proposed State of 
Missouri's reaction kindled fears of a renewed boundary fight. The new territorial governor, Democrat James Clarke, appointed by President James Polk in 1845, informed the Iowa legislature that the borderland remained at peace. Nonetheless, reports of a conflict between the sheriffs of Davis County, Iowa, and Schuyler County, Missouri, threatened to repeat the tensions of 1839. The solons of Jefferson City memorialized Congress that once again the "feelings of the people bordering upon the line have become excited, until a civil war is at any moment liable to be kindled." 69

In 1845 and 1846 Iowa politicians and federal officials negotiated the former's statehood through a series of debates about its boundaries, mostly relating to the northern and western limits of the proposed state. Its southern line received due attention as well. In early 1846 the territorial legislature asked congressional permission to seek a settlement with Missouri in the U.S. Supreme Court, a body often referenced as the proper arbiter of the matter. 70

Iowa's constitution as approved by the federal government in the summer of 1846 specified its southern boundary as corresponding with the northern line of Missouri created by its 1820 constitution, with no reference to the surveys of 1816 or the 1830s that had caused such friction. ${ }^{71}$ With Iowa's statehood at last realized, the two members of the Union could finally settle their long-standing dispute as equals.

AFTER YEARS OF BITTER WORDS and near-bloodshed, Missouri and Iowa met in the courtroom rather than on the battlefield in late 1847. Both states filed cross suits with the U.S. Supreme Court and sent lawyers to voice their arguments in its stately Doric room in the U.S. Capitol. Missouri's representative

Iowa May be Made to Conform to the Northern Boundary Line of the State of Missouri," 28th Cong., 2nd sess., 2/19/1845, S. Doc. 110, serial 456, 1.

69. Burlington Hawk-Eye, 12/11/1845; Negus, "Southern Boundary of Iowa," 786-87; "Boundary Line between Iowa and Missouri," 29th Cong., 1st sess., 2/5/1846, H. Doc. 104, serial 483, 2.

70. "Boundary Line between Iowa and Missouri," 29th Cong., 1st sess., 2/17/ 1846, H. Doc. 126, serial 483.

71. Burlington Hawk-Eye, 6/4/1846. 
claimed evidence of rapids in the Des Moines River that would support the 1837 survey line. By contrast, the Iowans focused their attention on defining the long-contested rapids, and insisted that only those in the Mississippi River could have been known in 1820 when Missouri's constitution referenced them. Without identifying which line should divide Missouri from Iowa, Iowa's lawyer disputed the premise on which his counterpart rested his case. ${ }^{72}$

The Supreme Court waited more than a year to render its verdict. Associate Justice John Catron delivered the unanimous opinion of his colleagues on February 13, 1849. The justices noted that Missouri's state boundaries as initially described in its constitution depended on the 1816 Sullivan boundary. It originally represented a separation between state power and American Indian land, held ultimately by the federal government, a condition that changed only semantically when Indian title gave way to territorial status. In addition, all public land surveys in the area relied on Sullivan's line. The court also mentioned the rapids upon which the line supposedly depended for an eastern terminus. It considered the Mississippi River's Des Moines rapids as the ones most likely referenced in treaty and law, and since the rapids extended 14 miles up the Mississippi, the line could intersect them anywhere and still be considered legal. ${ }^{73}$

The final arbitration of the Missouri-Iowa boundary, therefore, marked a victory for the brand new state to the north. Sullivan's 1816 survey line remains the official division between the two, extending due east from the Missouri River to the original northwest corner of Missouri, and from there slightly north of east to the Des Moines River, making an extreme obtuse angle. But considering the intense competition that had long complicated life in that borderland, the Supreme Court found it necessary to issue a stern reminder to both parties.

And it is further adjudged and decreed, that the State of Missouri be, and she is hereby, perpetually enjoined and restrained from exercising jurisdiction north of the boundary aforesaid dividing

72. Missouri v. Iowa, 48 U.S. 663-66 (1849).

73. Ibid., 666-77. 
the States; and that the State of Iowa be, and she hereby is, also perpetually enjoined and restrained from exercising jurisdiction south of the dividing boundary established by this decree. ${ }^{74}$

That statement might seem redundant in any other circumstance, but the legacy of the dispute demanded a strong message to remind Missouri and Iowa that their border war had come to an end.

By 1851 another survey marked the line between Missouri and Iowa, which allowed officials in Van Buren and Clark counties, among others along the boundary, to assess property and collect taxes in peace. ${ }^{75}$ Given the rapidly evolving nature of western American settlement, though, many who had lived through the 1839 conflict had moved on in the dozen years since. In particular, one newspaper noted the demise of that examplar of a borderland community, the "Hairy Nation." Shortly after the Supreme Court decision, "the disputed territory soon became thickly settled by industrious and thriving citizens, in the former places of the Hairy Nation, who gradually left for regions where there is more freedom and less labor, more whisky and less tax-paying than the State of Iowa was about to impose upon them." 76 In this case, the transformation from "borderlands into bordered lands," as Jeremy Adelman and Stephen Aron suggest, proceeded with marked similarity to that of many international borders. ${ }^{77}$

74. Ibid., 679 .

75. See Negus, "Southern Boundary of Iowa," 789-93. To read about a more recent survey of the Missouri-Iowa line, see Troy L. Hayes, "Missouri/Iowa Boundary Line Investigation," American Surveyor 3 (March-April 2006), 33-36.

76. Western Gazette, 5/13/1854.

77. Jeremy Adelman and Stephen Aron, "From Borderlands to Borders: Empires, Nation-States, and the Peoples in Between in North American History," American Historical Review 104 (1999), 816 (emphasis in original). In 1895 a similar dispute to the one in 1839 took place along the Iowa-Missouri line, about a hundred miles west of the "Honey War." A personal dispute along the line led an Iowa court to indict a Missourian who was arrested when he supposedly stepped north of the line. After paying bail he charged the Iowa authorities with kidnapping, and Missouri authorities arrested the Iowa sheriff, who was released when a friend from Iowa brandished weapons at the Missourians. A resurvey of the line settled the spiraling dispute, and transferred a little land from Iowa to Missouri. See Stevens, Centennial History of Missouri, 66; Franklin K. Van Zandt, Boundaries of the United States and the Several States (Washington, DC, 1966), 213-14. 
THE FIGHT over the Iowa-Missouri line merits special recognition among boundary disputes in the United States. For more than 40 years in the early nineteenth century, politicians and settlers struggled to establish authority over this contested region. But tax registers and court records were not the only issues up for grabs. More than anything else, this oftentimes ludicrous contest represented the lengths to which trans-Mississippi dwellers would go to protect what they believed was theirs, whether their land or their identity. After the Supreme Court finally adjudicated the boundary, an apocryphal story joked, "An old farmer, so it goes, was delighted to hear that the decision put him in Iowa, not Missouri, "cause I heard tell the climate ' $n$ ' soil of Missouri ain't fitten ter raise decent crops.'" 78

Invisible lines could make an otherwise cohesive landscape look quite different to the people who lived near them. Historians have generally interpreted the "Honey War," when they have interpreted it at all, as little more than an amusing episode in the region's heritage. In reality, the struggle represented something far more important. The line separating the two polities helped make one group Missourians and the other Iowans. Their willingness to defend that identity with force, "to shed our blood for our beloved Territory," illustrated the value they both ascribed to their common boundary. It made them not only Pukes and Hawkeyes, but also a part of the broader Union, shaped by similar lines that created such identities all across the United States.

78. Quoted in Clarence M. Conkling, "Look at the State They're In!," Saturday Evening Post, 10/20/1951, 194. 